\title{
MODEL PENERIMAAN TEKNOLOGI APLIKASI PEMASARAN PADA KOPERASI USAHA WANITA DUKUH MENANGGAL SURABAYA
}

\author{
Yitno Utomo'), Muhamad Abdul Jumali²) \\ ${ }^{1}$ Teknik Industri, Fakultas Teknik, Universitas PGRI Adi Buana Surabaya \\ email: yitno@unipasby.ac.id \\ ${ }^{2}$ Teknik Industri, Fakultas Teknik, Universitas PGRI Adi Buana Surabaya \\ email: abduljumali@unipasby.ac.id
}

\begin{abstract}
Koperasi Usaha Wanita (KOPWAN) memang menjadi idola perekonomian di Kota Surabaya, melalui konsep yang dibuat Walikota Surabaya menjadikan koperasi ini berkembang lebih cepat, kendala utama koperasi dalam persaingan usaha adalah penerapan teknologi, dimana kopearsi dituntut untuk mampu melayani proses penjualan dan pemasaran dalam suatu sistem aplikasi. Tujuan penelitian ini adalah untuk mengetahui model penerimaan teknologi yang terdiri dari persepsi kegunaan, persepsi kemudahan dan data produk terhadap penggunaan sesungguhnya serta terhadap transaksi pembelian pada Koperasi Usaha Wanita Dukuh Menanggal. Sampel dalam penelitian ini terdiri atas 173 orang dan analisa data dalam penelitian ini menggunakan metode SEM (Structural Equation Modeling). Hasil Analisa data bahwa terdapat tiga variabel yang memiliki pengaruh secara signifikan yaitu persepsi kegunaan terhadap transaksi pembelian, perilaku konsumen terhadap transaksi pembelian dan persepsi kegunaan terhadap transaksi pembelian pada aplikasi pemasaran Koperasi Usaha Wanita Dukuh Menanggal, hal ini dibuktikan dengan nilai Critical Ratio (CR) di atas 1,96 dan probabilitas $<0,05$.
\end{abstract}

Kata Kunci: TAM, Koperasi Usaha Wanita, Model SEM

\begin{abstract}
Koperasi Usaha Wanita (KOPWAN) has indeed become an economic idol in the city of Surabaya, through a concept made by the Mayor of Surabaya making this cooperative develop faster, the main cooperative cooperative in business competition is the application of technology, where cooperation is intended to be able to serve the sales and marketing process in a system. application. The purpose of this study was to determine the technology acceptance model consisting of perceived usefulness, ease of use and actual product at actual use as well as purchase transactions at the Koperasi Usaha Wanita Dukuh Menanggal. The sample in the study consisted of 173 people and data analysis in the study used the SEM (Structural Equation Modeling) method. The results of the data analysis show that there are three variables that have a significant influence, namely perceived usefulness on purchase transactions, consumer behavior (attitudes towards use) on purchase transactions and perceived benefits (perceived usefulness) on purchase transactions in the Koperasi Usaha Wanita Dukuh Menanggal marketing application On the date, this is evidenced by the Critical Ratio (CR) value above 1.96 and a probability $<0.05$.
\end{abstract}

Keywords: TAM, Koperasi Usaha Wanita, SEM Model 


\section{PENDAhuluan}

Koperasi Usaha Wanita (KOPWAN) memang menjadi idola perekonomian di Kota Surabaya, melalui konsep yang dibuat Walikota ini dinas koperasi dan UMKM telah menjalankan prioritas pengembangan ekonomi secara baik. Kopwan menjadi bisnis plan yang sangat menjanjikan, Konsep perencanaan bisnis yang harus diterapkan lebih pada pembuatan aturan-aturan yang dikaji atas dasar teori yang memungkinkan untuk diterapkan sebagai planning dalam mnjalankan bisnis. Dokumen-dokumen persiapan yang memuat hal-hal signifikan berkaitan perencanaan harus dapat tersusun dengan rapi, dan konsep-konsep ini sebagai upaya membetuk jiwa wirausaha yang kompeten. Koperasi ini akan dijadikan bisnis plan yang akan mewadahi semua kegiatan perempuan di wilayah Kecamatan Gayungan Kota Surabaya.

Koperasi Usaha Wanita sering menjadi tunpuan dalam pemberdayaan perekonomian masyarakat desa, seperti halnya pendapat Ratnasari (2011) bahwa melalui pengembangan kapasitas (capacity building) yang meliputi pengembangan sumber daya manusia, penguatan organisasi, reformasi kelembagaan, partisipasi anggota dan diversifikasi usaha. Koperasi Usaha Wanita diharapkan berdampak pada optimalisasi sisa hasil usaha (SHU). Tidak jauh berbeda dengan koperasi yang berada di desa Sooko Mojokerto bahwa Model pemberdayaan ekonomi melalui Fasilitasi Perkuatan Usaha Program Dana Bergulir. (Augustinah, 2017)

Koperasi juga tidak terlepas dari sentuhan modernisasi, pelayanan koperasi harus juga bergantung pada pesatnya teknologi, pelayanan dengan menggunakan internet juga harus dikembangkan. Pemasaran modern, harus menjadi ciri khas organisasi ini. Menurut Utomo (2018) kehandalan teknologi dalam proses pemasaran dapat diukur dengan Technology Acceptance Model (TAM) dimana masyarakat dapat dapat menilai konstruk kemudahan sebagai upaya pendukung transaksi elektronik. Begitu juga Kuncoro (2016) menyatakan bentuk atribut kehandalan (realiability) menunjukkan nilai yang baik namun juga disarankan agar dilakukan inovasi layanan yang lebih cepat. Tasmil (2015) juga dalam penelitiannya menunjukkan dari 7 (tujuh) hipotesis yang diadopsi dari model TAM yang telah diuji, penggunaan sesungguhnya (AU) bernilai sig. 6.8354 (> 1,96) hasil terbaik dalam pengukuran penerimaan teknologi bagi nelayan dalam penggunaan GPS, konsep penerimaan teknologi memang saat ini harus menjadi acuan keberhasilan organisasi dalam memberikan pelayanan secara cepat kepada masyarakat.

Koperasi usaha wanita sebagai inkubasi startup dengan konsep virtual marketing diharapkan mampu menjadi pioneer perkembangan koperasi masa depan, mengingat badan usaha yang resmi ini jarang sekali dilirik oleh konsumen pada umumnya, sedangkan koperasi sebenanrnya badan usaha yang diresmikan oleh negara serta mendapat pantauan serta binaan secara eksklusif, dikatakan eksklusif karena dana-dana binaan dari dinas sangat banyak. Koperasi usaha wanita sangat mudah berkembang karena lingkupnya yang mudah untuk masyarakat tanpa birokrasi yang rumit dan penyelesain permasalahan di selesaikan secara cepat dan membangun kapasitas. (Yuka, 2011)

Koperasi Usaha Wanita (KOPWAN) Kecamatan Gayungan Kota Surabaya melalui kerjasama dengan dosen universitas PGRI Adi Buana dalam program penelitian Hibah Adibuana ini akan berusaha membantu secara maksimal dalam pemasaran, konsep virtual marketing akan membuat website yang dipergunakan untuk memudahkan proses transaksi dan pelayanan pada konsumen. Tujuan penelitian ini untuk mengetahui model penerimaan teknologi yang terdiri dari persepsi kegunaan (Perceived usefulness), kemudahan (perceived ease of use) dan data produk terhadap penggunaan sesungguhnya (actual usage) serta terhadap transaksi pembelian pada Koperasi Usaha Wanita Dukuh Menanggal.

\section{METODE}

Variabel penelitian ini terdiri atas variable eksogen yang meliputi : Persepsi Kegunaan $\left(\mathrm{X}_{1}\right)$, Persepsi Kemudahan $\left(\mathrm{X}_{2}\right)$ dan Persepsi Data Produk $\left(\mathrm{X}_{3}\right)$ selanjutnya variabel endogen yang meliputi : perilaku konsumen $\left(\mathrm{Y}_{1}\right)$ dan transaksi pembelian $\left(\mathrm{Y}_{2}\right)$

Sampel dalam penelitian ini terdiri atas 173 orang yang merupakan warga Dukuh Menanggal yang diperoleh dengan Teknik 
sampling berupa Accidental sampling. Kemudian Analisa data dalam penelitian ini menggunakan metode SEM. Hal ini dipilih karena analisa SEM mampu mengidentifkasi model dengan hasil yang komprehensip, sehingga data-data pada indikator variabel dapat terbentuk secara benar dan nyata.

\section{HASIL DAN PEMBAHASAN}

\section{Data Identitas Responden}

Sumber data yang merupakan bagian dari informasi tentang bahan penelitian ini diperoleh berdasarkan penyebaran kuesioner, maka sangat diperlukan informasi tentang data responden, mengingat responden merupakan warga Kota Surabaya terutama di Kelurahan Dukuh Menanggal yang menjadi pelanggan Koperasi Usaha Wanita sebanyak 173 orang.

Tabel 1. Identitas Responden

\begin{tabular}{lll}
\hline Indentitas & Frekuensi & \% \\
\hline Jenis Kelamin & & \\
$\quad$ Laki-Laki & 23 & 13,3 \\
$\quad$ Perempuan & 150 & 86,7 \\
Usia & & \\
$\quad<20$ tahun & 39 & 22,5 \\
20-50 tahun & 115 & 66,5 \\
$\quad$ 50 tahun & 19 & 11,0 \\
Jenis Layanan & & \\
Transaksi beli & 117 & 67,6 \\
Cek harga & 48 & 27,7 \\
$\quad$ Lainnya & 8 & 4,6 \\
Jumlah & $\mathbf{1 7 3}$ & $\mathbf{1 0 0}$ \\
\hline
\end{tabular}

Berdasarkan jenis kelamin data responden pengguna aplikasi pemasaran koperasi usaha wanita menunjukkan bahwa perempuan lebih banyak yaitu mencapai $86,7 \%$

Berdasarkan usia data responden pengguna aplikasi pemasaran koperasi usaha wanita menunjukkan bahwa yang berusia 20 sampai dengan 50 tahun lebih banyak yaitu mencapai $66,5 \%$

Berdasarkan jenis layanan yang digunakan data responden pengguna aplikasi pemasaran koperasi usaha wanita menunjukkan bahwa penggunaan untuk transaksi pembelian lebih banyak yaitu mencapai $67,6 \%$

\section{Confirmatory Factor Analysis (CFA)}

CFA adalah Confirmatory Factor Analysis yang fungsi sebenarnya untuk menguji bahwa cata-data itu valid dalam uji validitas dan realibel ketika di uji realibilitas pada variabelvariabel laten.

\section{a. CFA Kegunaan Aplikasi (X1)}

$C F A$ dapat digunakan untuk mengukur konstruk laten Persepsi kegunaan / Perceived Usefulness (X1) yang merupakan konstruk undimensional yang didefinisikan oleh 3 indikator. Secara grafis, konstruk laten Persepsi Kegunaan (X1) dapat digambarkan pada gambar 1 sebagai berikut.
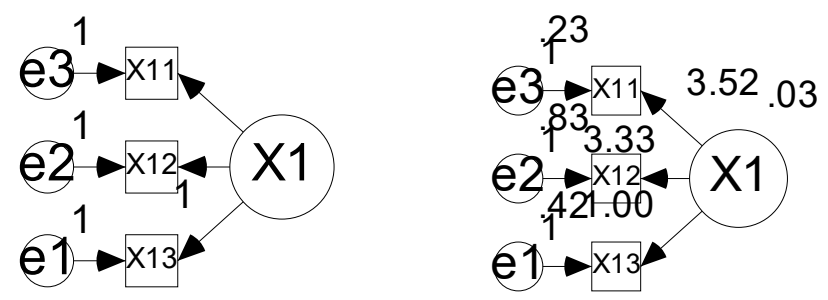
Gambar 1. CFA Variabel Laten Persepsi Kegunaan Aplikasi

Hasil analisa dari gambaran model Goodness of fit (GOF) ditunjukkan sebagai berikut :

Tabel 2. Goodness of fit Model Modifikasi CFA Variabel Persepsi Kegunaan Aplikasi

\begin{tabular}{lcl}
\hline $\begin{array}{l}\text { Goodness of Fit } \\
\text { Index }\end{array}$ & $\begin{array}{c}\text { Hasil } \\
\text { Model }\end{array}$ & Keterangan \\
\hline $\begin{array}{l}\text { Chi-Square }\left(\chi^{2}\right) \\
\text { Probability }\end{array}$ & 8,909 & Model baik \\
(PValue) & 0,113 & Model baik \\
GFI & & \\
AGFI & 0,983 & Model baik \\
RMSEA & 0,929 & Model baik \\
CFI & 0,067 & Model baik \\
TLI & 0,959 & Model baik \\
& 0,877 & Kurang \\
\hline
\end{tabular}

Berdasarkan tabel tersebut dapat dilihat bahwa model CFA sudah memenuhi kriteria Goodness of fit. Karena nilai probability (P Value) pengujian goodness of fit menunjukkan nilai 0,113 . Hasil Analisa menyatakan bahwa 
seluruh indikator variable pada pertanyaan Persepsi kegunaan aplikasi (X1) sesuai.

\section{b. CFA Kemudahan Aplikasi (X2)}

$C F A$ dapat digunakan untuk mengukur konstruk laten Persepsi Kemudahan / Perceived Ease of Use (X2) yang merupakan konstruk undimensional yang didefinisikan oleh 3 indikator. Secara grafis, konstruk laten Persepsi Kemudahan (X2) dapat digambarkan pada gambar sebagai berikut
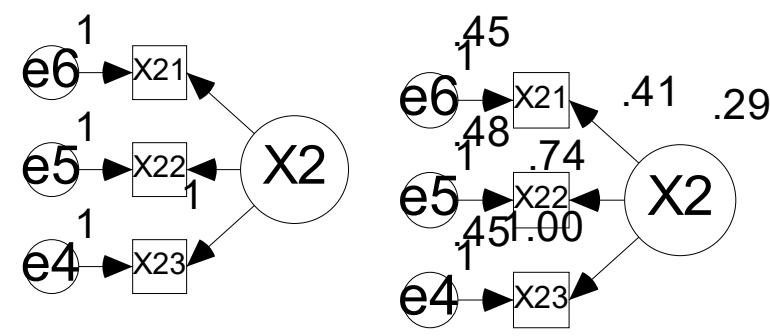

Gambar 2. CFA Variabel Laten Persepsi Kemudahan Aplikasi

Kemudian hasil Goodness of fit (GOF) ditunjukkan kembali sebagai berikut.

Tabel 3. GOF Model Modifikasi CFA Variabel Persepsi Kemudahan

\begin{tabular}{lcc}
\hline $\begin{array}{l}\text { Goodness of Fit } \\
\text { Index }\end{array}$ & $\begin{array}{c}\text { Hasil } \\
\text { Model }\end{array}$ & Keterangan \\
\hline $\begin{array}{l}\text { Chi-Square }\left(\chi^{2}\right) \\
\begin{array}{l}\text { Probability } \\
\text { (PValue) }\end{array}\end{array}$ & 7,534 & Model baik \\
GFI & 0,184 & Model baik \\
AGFI & 0,986 & Model baik \\
RMSEA & 0,941 & Model baik \\
CFI & 0,054 & Model baik \\
TLI & 0,991 & Model baik \\
\hline
\end{tabular}

Berdasarkan tabel tersebut dapat dilihat bahwa model CFA sudah memenuhi kriteria GOF. Karena nilai probability (P Value) pengujian $G O F$ menunjukkan nilai 0,184 . Hasil Analisa menyatakan bahwa seluruh indikator variable pada pertanyaan Persepsi kemudahan aplikasi (X1) sesuai.

\section{c. CFA Data Produk (X3)}

$C F A$ dapat digunakan untuk mengukur konstruk laten Persepsi Data Produk (X3) yang merupakan konstruk undimensional yang didefinisikan oleh 3 indikator. Secara grafis, konstruk laten Persepsi Data Produk (X3) dapat digambarkan pada gambar sebagai berikut
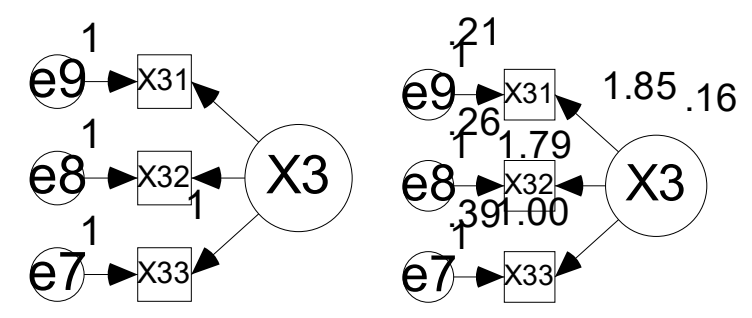

Gambar 3. CFA Variabel Laten Persepsi Data Produk

Untuk hasil GOR dari variabel laten persepsi data produk adalah sebagai berikut :

Tabel 4. GOF Model Modifikasi CFA Variabel Persepsi Data Produk

\begin{tabular}{lcc}
\hline $\begin{array}{l}\text { Goodness of Fit } \\
\text { Index }\end{array}$ & $\begin{array}{c}\text { Hasil } \\
\text { Model }\end{array}$ & Keterangan \\
\hline $\begin{array}{l}\text { Chi-Square }\left(\chi^{2}\right) \\
\text { Probability } \\
\text { (PValue) }\end{array}$ & 3,508 & Model baik \\
GFI & 0,127 & Model baik \\
AGFI & 0,936 & Model baik \\
RMSEA & 0,982 & Model baik \\
CFI & 0,023 & Model baik \\
TLI & 0,987 & Model baik \\
\hline
\end{tabular}

Berdasarkan tabel tersebut dapat dilihat bahwa model CFA sudah memenuhi kriteria GOF. Karena nilai probability (P Value) pengujian $G O F$ menunjukkan nilai 0,127. Hasil Analisa menyatakan bahwa seluruh indikator variabel pada pertanyaan Persepsi data produk (X3) sesuai.

\section{d. CFA Perilaku Konsumen (Y1)}

CFA dapat digunakan untuk mengukur konstruk laten Persepsi perilaku konsumen (Y1) yang merupakan konstruk undimensional 
yang didefinisikan oleh 3 indikator. Secara grafis, konstruk laten perilaku konsumen (Y1) dapat digambarkan pada gambar sebagai berikut
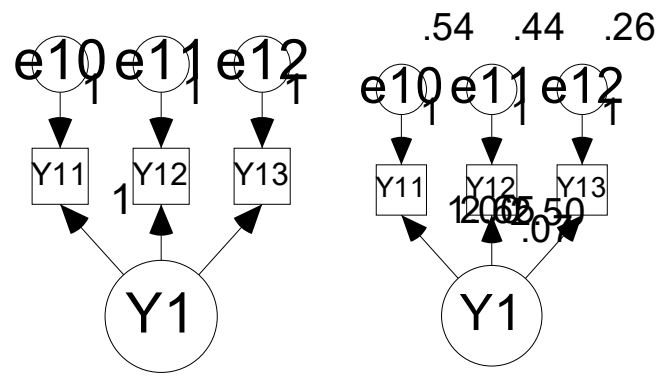

\section{Gambar 4. Modifikasi CFA Variabel Laten Perilaku Konsumen}

Pengujian $G O F$ untuk variabel perilaku konsumen adalah sebagai sebagai berikut.

Tabel 6. Goodness of fit Model Modifikasi CFA Variabel Perilaku Konsumen

\begin{tabular}{lcl}
\hline $\begin{array}{l}\text { Goodness of Fit } \\
\text { Index }\end{array}$ & $\begin{array}{c}\text { Hasil } \\
\text { Model }\end{array}$ & Keterangan \\
\hline $\begin{array}{l}\text { Chi-Square }\left(\chi^{2}\right) \\
\text { Probability }\end{array}$ & 7,519 & Model baik \\
(PValue) & 0,471 & Model baik \\
GFI & & \\
AGFI & 0,998 & Model baik \\
RMSEA & 0,985 & Model baik \\
CFI & 0,000 & Model baik \\
TLI & 1,000 & Model baik \\
\hline
\end{tabular}

Berdasarkan tabel tersebut dapat dilihat bahwa model CFA sudah memenuhi kriteria Goodness of fit. Karena nilai probability (P Value) pengujian goodness of fit menunjukkan nilai 0,471 . Hasil Analisa menyatakan bahwa seluruh indikator variabel pada pertanyaan Persepsi perilaku konsumen (Y1) sesuai.

\section{d. CFA Transaksi Pembelian (Y2)}

$C F A$ dapat digunakan untuk mengukur konstruk laten Persepsi transaksi pembelian (Y2) yang merupakan konstruk undimensional yang didefinisikan oleh 4 indikator. Secara grafis, konstruk laten transaksi pembelian (Y2) dapat digambarkan pada gambar sebagai berikut

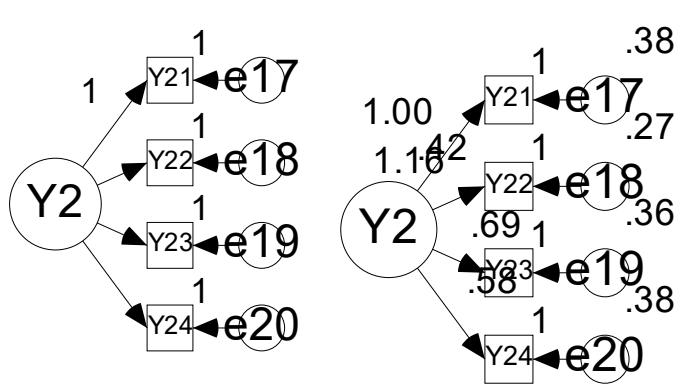

Gambar 5. Modifikasi CFA Variabel Laten Transaksi Pembelian

Kemudian hasil pengujian Goodness of fit pada transaksi pembelian adalah sebagai berikut.

Tabel 7. Goodness of fit Model Modifikasi CFA Variabel Transaksi Pembelian

\begin{tabular}{lcc}
\hline $\begin{array}{l}\text { Goodness of Fit } \\
\text { Index }\end{array}$ & $\begin{array}{c}\text { Hasil } \\
\text { Model }\end{array}$ & Keterangan \\
\hline $\begin{array}{l}\text { Chi-Square }\left(\chi^{2}\right) \\
\begin{array}{l}\text { Probability } \\
\text { (PValue) }\end{array}\end{array}$ & 6,843 & Model baik \\
GFI & 0,445 & Model baik \\
AGFI & 0,987 & Model baik \\
RMSEA & 0,962 & Model baik \\
CFI & 0,019 & Model baik \\
TLI & 1,000 & Model baik \\
\hline
\end{tabular}

Berdasarkan tabel tersebut dapat dilihat bahwa model CFA sudah memenuhi kriteria $G O F$. Karena nilai probability (P Value) pengujian $G O F$ menunjukkan nilai 0,445 . Hasil Analisa menyatakan bahwa seluruh indikator variabel pada pertanyaan Persepsi transaksi pembelian (Y2) sesuai.

\section{Pengolahan Model SEM Keseluruhan}

Structural Equation Modelling (SEM) menggunakan software AMOS dengan cara menggambar model dan memasukkan data, kemudian melakukan running sehingga mendapatkan model yang fit. Model dapat dilihat pada gambar 7 dibawah ini, untuk permodelan pertama. 


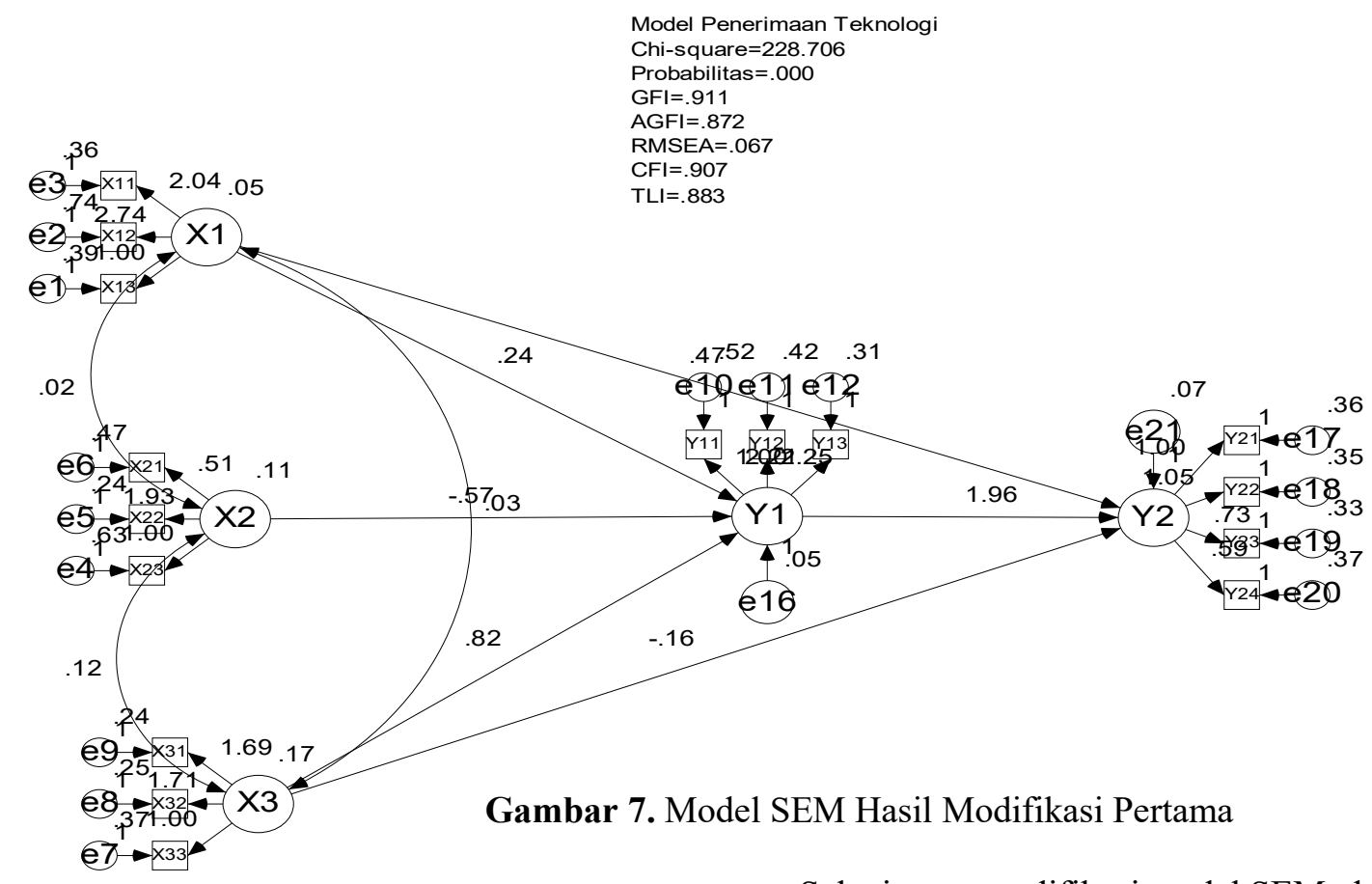

Selanjutnya modifikasi model SEM, dapat

Selanjutnya dilakukan tahapan evaluasi untuk kesesuain model. Model dikatakan baik jika nilai kesesuaian model (goodness of fit) sesuai dengan kriteria. Nilai goodness of fit untuk model keseluruhan dapat dilihat pada tabel 7 berikut ini :

Tabel 7. Goodness of fit Model SEM Keseluruhan

\begin{tabular}{lccl}
\hline $\begin{array}{c}\text { Goodness } \\
\text { of Fit } \\
\text { Index }\end{array}$ & $\begin{array}{c}\text { Cut Off } \\
\text { Value }\end{array}$ & $\begin{array}{c}\text { Hasil } \\
\text { Model }\end{array}$ & Keterangan \\
\hline $\begin{array}{l}\text { Chi- } \\
\text { Square }\left(\chi^{2}\right)\end{array}$ & $\begin{array}{c}\text { Diharapkan } \\
\text { nilai kecil } \\
\text { Probability }\end{array}$ & 732,702 & Kurang Baik \\
(PValue) & $\geq 0,05$ & 0,000 & Kurang Baik \\
GFI & $\geq 0,90$ & 0,803 & Kurang Baik \\
AGFI & $\geq 0,90$ & 0,754 & Kurang Baik \\
RMSEA & $\leq 0,08$ & 0,092 & Kurang Baik \\
CFI & $\geq 0,95$ & 0,722 & Kurang Baik \\
TLI & $\geq 0,95$ & 0,684 & Kurang Baik \\
\hline
\end{tabular}

Berdasarkan tabel 7 di atas dapat dihasilkan keputusan bahwa GOF yang dihasilkan masih menunjukkan hasil yang belum maksimal sehingga korelasi residual indicator sangat diperlukan lagi. diperoleh hasil modifikasi berikutnya yang merupakan modifikasi terakhir, maka langkah selanjutnya perlu dilakukan pengujian Goodness of fit kembali sebagai berikut.

Tabel 8: Goodness of fit Model SEM Keseluruhan Modifikasi Kedua

\begin{tabular}{lccl}
\hline $\begin{array}{c}\text { Goodness } \\
\text { of Fit } \\
\text { Index }\end{array}$ & $\begin{array}{c}\text { Cut Off } \\
\text { Value }\end{array}$ & $\begin{array}{c}\text { Hasil } \\
\text { Model }\end{array}$ & Keterangan \\
\hline $\begin{array}{l}\text { Chi- } \\
\text { Square }\left(\chi^{2}\right)\end{array}$ & $\begin{array}{c}\text { Diharapkan } \\
\text { nilai kecil }\end{array}$ & 164,063 & Model baik \\
$\begin{array}{l}\text { Probability } \\
\text { (PValue) }\end{array}$ & $\geq 0,05$ & 0,081 & Model baik \\
GFI & $\geq 0,90$ & 0,943 & Model baik \\
AGFI & $\geq 0,90$ & 0,918 & Model baik \\
RMSEA & $\leq 0,08$ & 0,021 & Model baik \\
CFI & $\geq 0,95$ & 0,956 & Model baik \\
TLI & $\geq 0,95$ & 0,961 & Model baik \\
\hline
\end{tabular}

Berdasarkan tabel 8 dapat dilihat bahwa model SEM keseluruhan sudah memenuhi kriteria GOF. Hal ini menunjukkan bahwa indikator-indikator yang digunakan dalam mengukur masing-masing variabel laten telah sesuai. Maka model kedua (Gambar 8) yang digambarkan dibawah ini menjadi model yang diajukan, dan dapat diambil keputusan Analisa. 


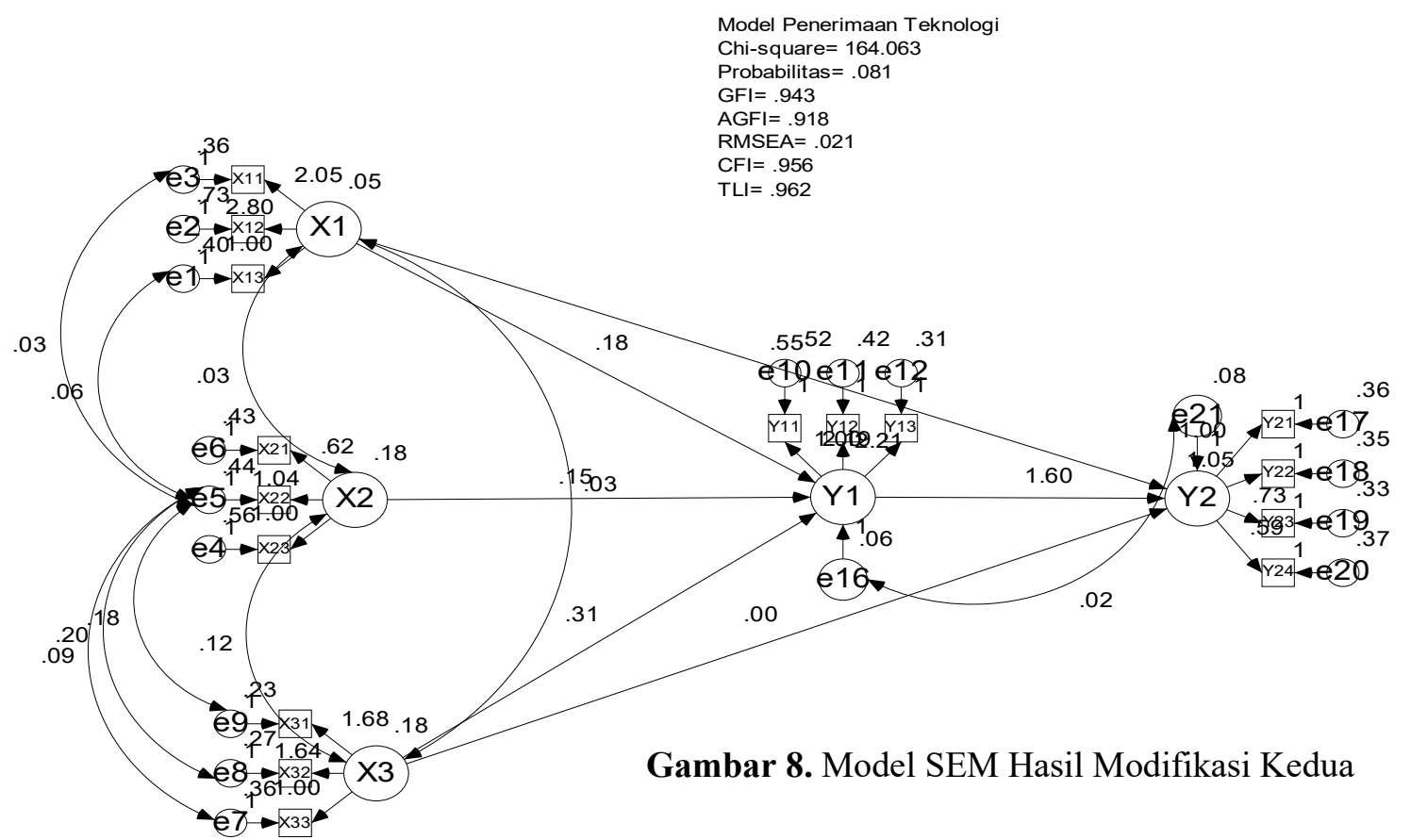

\subsubsection{Pengujian Hipotesis}

Berdasarkan tabel 9 menunjukkan bahwa hasil pengukuran telah memenuhi kriteria goodness of fit dan tabel tersebut menunjukkan adanya nilai estimasi pengaruh pada masingmasing parameter, maka selanjutnya akan dilakukan pengujian terhadap 7 hipotesis yang diajukan dalam penelitian ini, dan diterima 3 hipotesis.

\section{Tabel 9. Estimasi Parameter Model SEM untu Uji hipotesis}

\begin{tabular}{llrrrrl}
\hline & & Estimate & S.E. & \multicolumn{1}{c}{ C.R. } & P & Label \\
\hline Y1 <--- & X2 & -.574 & .425 & -1.354 & .177 & \\
Y1 <--- & X1 & .237 & .137 & 1.730 & .084 & \\
Y2 <--- & X3 & .818 & .346 & 2.364 & .018 & \\
$\mathrm{Y} 2<---$ & Y1 & 1.958 & .356 & 5.497 & $* * *$ & par_21 \\
Y2 <--- & X3 & -.156 & .129 & -1.212 & .225 & par_20 \\
Y2 <--- & X1 & .473 & .227 & 2.083 & .037 & par_17 \\
\hline
\end{tabular}

\section{a. Pengujian Hipotesis 1}

H1 : Ada pengaruh persepsi kegunaan (Perceived usefulness) terhadap transaksi pembelian pada aplikasi pemasaran Koperasi Usaha Wanita Dukuh Menanggal.
Hubungan variabel antara X1 terhadap Y2 dapat ditunjukkan hasil signifikansi, dengan $\mathrm{CR}=2,083$ atau $\mathrm{CR} \geq 1,96$ untuk taraf signifikansi $5 \%$ dan nilai p-value yang dihasilkan adalah 0,037 sehingga keputusannya yaitu $\mathrm{H} 1$ diterima sehingga ada pengaruh persepsi kegunaan (Perceived usefulness) terhadap transaksi pembelian pada aplikasi pemasaran Koperasi Usaha Wanita Dukuh Menanggal. Berdasarkan pendapat Agustian (2014) bahwa TAM yang digunakan untuk mengukur pemanfaat internet bagi UKM memiliki kencenderungan sama yaitu mengutamakan persepsi kegunaan sebagai indikator keberhasilannya.

\section{b. Pengujian Hipotesis 2}

H2 : Ada pengaruh persepsi data produk terhadap transaksi pembelian pada aplikasi pemasaran Koperasi Usaha Wanita Dukuh Menanggal.

Daerah kritis : di tolak $\mathrm{H}_{0}$ jika nilai p-value kurang dari $\alpha=5 \%$

Pada hubungan variabel X3 terhadap Y2 signifikansi hasil analisa juga bagus, dengan $\mathrm{CR}=2,364$ atau $\mathrm{CR} \geq 1,96$ untuk taraf signifikansi $5 \%$ dan nilai p-value yang dihasilkan adalah 0,000 sehingga keputusannya yaitu $\mathrm{H} 3$ diterima sehingga Ada pengaruh persepsi data produk terhadap transaksi pembelian pada aplikasi pemasaran Koperasi Usaha Wanita Dukuh Menanggal. 
Menurut Handayani (2016) bahwa sebagian pelanggan menganggap bahwa keputusan akhir dari sebuah peranan teknologi adalah jika konsumen melakukan transaksi sebenarnya (Actual Usage).

\section{b. Pengujian Hipotesis 3}

H3 : Ada pengaruh persepsi perilaku konsumen (attitude toward using ) terhadap transaksi pembelian pada aplikasi pemasaran Koperasi Usaha Wanita Dukuh Menanggal.

Daerah kritis : di tolak $\mathrm{H}_{0}$ jika nilai p-value kurang dari $\alpha=5 \%$

Hasil analisa hubungan variabel Y1 terhadap Y2 memiliki tingkat signifikasi yang baik, dengan $\mathrm{CR}=5,497$ atau $\mathrm{CR} \geq 1,96$ untuk taraf signifikansi $5 \%$ dan nilai $\mathrm{p}$-value yang dihasilkan adalah 0,018 sehingga keputusannya yaitu $\mathrm{H} 2$ diterima sehingga Ada pengaruh persepsi persepsi perilaku konsumen (attitude toward using) terhadap transaksi pembelian pada aplikasi pemasaran Koperasi Usaha Wanita Dukuh Menanggal. Sejalan dengan pemikiran Jogiyanto (2011) bahwa persepsi persepsi perilaku konsumen (attitude toward using ) selalu dihubungkan dengan kemudahan dalam mengurangi proses pekerjaan atau seseorang terbantu atas aplikasi yang digunakan, sehingga perilaku ini dianggap wajar.

\section{KESIMPULAN}

Berdasarkan hasil Analisa data bahwa terdapat tiga variabel yang memiliki pengaruh secara signifikan yaitu persepsi kegunaan terhadap transaksi pembelian, perilaku konsumen terhadap transaksi pembelian dan persepsi kegunaan terhadap transaksi pembelian pada aplikasi pemasaran Koperasi
Usaha Wanita Dukuh Menanggal, hal ini dibuktikan dengan nilai Critical Ratio (CR) di atas 1,96 dan probabilitas $<0,05$.

\section{UCAPAN TERIMAKASIH}

Ucapan terimakasih disampaikan kepada pengelola Koperasi Usaha Wanita serta anggotanya yang hamper mencapai 300 orang di Kelurahan Dukuh Menanggal, serta tidak lupa bahwa penelitian ini juga atas dukungan Lurah Dukuh Menanggal serta kelompok UKM Amanah yang telah membantu pendataan responden sebagai sampel penelitian. 


\section{REFERENSI/DAFTAR PUSTAKA}

Agustian, W., \& Syafari, R. (2014). Pendekatan Technology Acceptance Model (TAM) untuk Mengidentifikasi Pemanfaatan Internet Usaha Kecil dan Menengah Sumatera Selatan. Seminar Nasional Teknologi Informasi \& Komunikasi Terapan (SEMANTIK 2014) (pp. 144153). Palembang: ISBN:979-26-0276-3.

Augustinah, F. (2017). Peran Koperasi Wanita (Kopwan) dalam Rangka Pemberdayaan Ekonomi Masyarakat Pada Kawasan Rawan Bencana di wilayah Kabupaten Mojokerto. Dialektika Volume 2 Nomor 1, 12-19.

Handayani, W., \& Harsono, M. (2016). Aplikasi Technology Acceptance Model (TAM) pada Komputerisasi Kegiatan Pertanahan. Economia, 36-42.

Jogiyanto. (2011). Sistem Informasi Keperilakuan. Yogyakarta: Penerbit Andi.

Kuncoro, D. J. (2016). Studi Deskriptif Tentang Kualitas Pelayanan Penanganan Pelanggan Perusahaan Daerah air Minum Kota Surabaya. Kebijakan dan Manajemen Publik, 45-53.

Ratnasari, D. D., Saleh, C., \& Rozikin, M. (2011). Optimalisasi Peran Koperasi wanita Dalam Meningkatkan Kesejahteraan Anggota (Studi pada Kopearsi Wanita Potre Koneng Kabupaten Sumenep). JAP, 51-60.

Tasmil, \& Herman. (2015). Penerapan Model TAM untuk menilai Tingkat Penerimaan Nelayan. Pekommas , 161-170.

Utomo, Y., \& Walujo, D. A. (2018). Penerapan Konstruk Technology Acceptance Model (TAM) pada Layanan Mobile Application di PDAM Surya Sembada Kota Surabaya. WAKTU, 3948.

Yuka, P. (2011). Capacity Building Organisasi Sektor Publik (Studi pada Badan Pemberdayaan Masyarakat Kabupaten Madiun). Malang: UB Press. 